\title{
How customer relationship management, perceived risk, perceived service quality, and passenger trust affect a full-service airline's passenger satisfaction
}

\author{
Suchat Lainamngern \\ Sudaporn Sawmong \\ King Mongkut's Institute of Technology Ladkrabang (KMITL) \\ Faculty of Administration and Management, Bangkok, Thailand
}

\section{Keywords}

Asian aviation; FSC; National carrier; Structural Equation Model (SEM); Thai Airways; Thailand

\begin{abstract}
In 2017, global international tourist arrivals set a new record of 1.32 billion individuals. From this, Thailand moved into the $10^{\text {th }}$ spot with 35.4 million visitors, and US $\$ 57.5$ billion in tourism earnings, which represented $12 \%$ of Thailand's GDP. Therefore, given the critical nature of tourism to Thailand's economy and the national carrier's role, the authors sought to investigate how customer relationship management $(C R M)$, perceived risk (PR), perceived service quality, and passenger trust (PT) affected Thai Airways' passenger satisfaction (PS). The research tool developed for the survey consisted of a questionnaire which used a seven-level, Likert type agreement scale for 34 items in Part 2. The study also conducted both a confirmatory factor analysis (CFA) and a structural equation model (SEM) to analyze the sample of 565 Thai Airways' passengers. A latent variable path analysis was performed using LISREL 9.1 software, with the models found to be consistent with empirical data. The causal factors in the model had both a positive and negative influence on Thai Airways passenger satisfaction (PS), which can be explained by $14 \%$ of the variance $\left(R^{2}\right)$. The four variables ranked in importance included customer relationship management (CRM), perceived risk (PR), passenger trust (PT), and perceived service quality (PSQ), which had a total value of $1.00,-0.35,0.20$ and 0.11 , respectively.
\end{abstract}

Corresponding author: Suchat Lainamngern

Email addresses for the corresponding author: suchat.numngern@gmail.com

First submission received: $1^{\text {st }}$ September 2018

Revised submission received: $5^{\text {th }}$ October 2018

Accepted: 29th October 2018

\subsection{Introduction}

Due to fast-paced economic growth within the Asian 'tiger economies', there has been a knock-on effect and surge in air travel demand. Despite unfavorable external shocks such as natural disasters, war, and terrorism (Hogan, 2017), economic turbulence, and fuel price increases, the global air travel industry has grown at a compound annual growth rate [CAGR] over 10 years of 5.5\%. In 2017 alone, global revenue per passenger kilometer rose $7.6 \%$ over 2016, and international passenger traffic increased $7.9 \%$, capacity rose $6.4 \%$, and load factors climbed to $80.6 \%$. Additionally, according to the United Nations World Tourism Organization [UNWTO], global international tourist arrivals rose to a record of 1.32 billion. From this, Thailand moved into the $10^{\text {th }}$ spot, with 35.4 million visitors, and US $\$ 57.5$ billion in tourism earnings. This represents $12 \%$ of Thailand's GDP (ASEAN Today, 2018).

Data from the Asia-Pacific region also shows Asian carriers even did better, which posted annual demand growth of $9.4 \%$ over 2016. This was driven by robust regional economic expansion, and an increase in route options for travelers (IATA, 2017). Asia-Pacific led all the regions in annual growth rate, with capacity rising $7.9 \%$, and load factors climbing to $79.6 \%$.

Contributing factors to these stellar numbers has been the rising per-capita income within the region, affordability of air travel, the rise of low-cost carriers (LCCs), open sky agreements, reduction in global fuel prices, and easing of visa restrictions (ASEAN Today, 2018; Charoensuthipan, 2018; Dupont, 2014; Vuthisopon and Srinuan, 2017). By 2036, Asia will be the world's largest aviation market as it 
continues at a growth rate of CAGR of $5.7 \%$ (IATA, 2017). Also, according to America's aircraft manufacturer Boeing, to meet booming demand, 43,000 new aircraft will be needed over the next two decades (Boeing upgrades aircraft forecast, 2018). European arch-rival Airbus has also forecast similar numbers, and has suggested that within the next two decades, the world's passenger fleet would more than double to 48,000 aircraft. Airbus has put the global value of nearly 37,400 new aircraft at US $\$ 5.8$ trillion by 2037.

Within Asia, Thailand has grown to be a popular international tourist destination as well. Located in Southeast Asia, Thailand's Airports of Thailand (AOT) has reported that in 2017 the Kingdom transited 129.2 million passengers (The International Trade Administration, 2018). Furthermore, there were 823,575 aircraft takeoffs and landings in 2017, an increase from 790,194 in 2016, with air cargo also showing a significant increase, rising to 1.60 million tons in 2017 from 1.45 million tons in 2016.

Commercial aviation, therefore, plays a critical role in a nation's economy, with international aviation closely related to the expansion of tourism, of which $55 \%$ is done by air (UNWTO, 2018, p.4). Aviation's importance to the world's economy can be found in the 2016 international tourist arrivals (overnight visitors) statistics, which reached 1.235 billion individuals and US\$1.2 trillion in the same year. Also, according to the UNWTO (2018), international tourism generated an additional US\$216 billion in exports through international air passenger transport services, bringing the total value of tourism exports to US\$1.4 trillion, or US $\$ 4$ billion a day on average. This represents $7 \%$ of the world's exports of goods and services and $30 \%$ of services exports alone.

Although numerous full-service carriers (FSCs) and low-cost carriers (LCC) fly to Thailand, the national carrier for Thailand is Thai Airways, which was created by the Thai government in March 1960. Sometime later, on July 19, 1991, the national carrier became listed on the Stock Exchange of Thailand (SET), which today is serving over 80 destinations worldwide (Thai Airways Annual Report, 2017).

However, even despite past and projected growth, Thai Airways has faced various and significant problems in recent years. According to the Thai Airways Annual Report (2017), this has included a decrease in competitiveness, unprofitable routes outnumbering profitable ones, a wide range of aircraft types resulting in higher maintenance cost, inefficient overall cost management, and inappropriate human resource management (HRM) and development. Moreover, intense and fast-changing competitive conditions within the airline business has caused the airline continued losses, contributing to an inability to recover.

Furthermore, low-cost carrier (LCC) competition has been tough year after year, with FSC national carriers such as Thai Airways, Malaysian Airways, and now even Singapore Airways, finding profitability and market share ever more challenging to obtain (Srisook and Panjakajornsak, 2017). An example of this dilemma, Thai Airways which after a net loss of $\$ 445$ million in 2014, had their debt skyrocket to US\$5.9 billion, the highest among Southeast Asian airlines (DuPont, 2017). However, Thai Airways is not alone, as Duport (2015) has reported that there are less than five profitable LCCs in the region (for 24 airlines), and barely ten FSCs out of around 40.

In 2017 global airlines also carried an estimated 1.2 billion passengers, with Southeast Asian passenger traffic growing by approximately 10\%. Southeast Asian airlines now have 1,600 airplanes on order (Tani, 2018), in addition to an active fleet of close to 2,000 airplanes, with LCCs currently accounting for approximately $70 \%$ of Thailand's domestic seat capacity. Also, in Thailand over the past five years, the domestic market has grown dramatically due to economic growth and an expanding middle class. This has led to rapid LCC expansion from approximately 11 million passenger seats in 2012, to 33 million in 2017 (Centre for Aviation, 2018).

As we can see, Thai Airways has significant challenges to overcome, both internally and externally. However, given the importance of Thai Airways being the national carrier, the authors undertook a study to investigate how the variables customer relationship management (CRM), perceived service quality (PSQ), perceived risk (PR), and passenger trust (PT), affected Thai Airways passenger satisfaction (PS). It is hoped that from this research, a more sustainable and competitive solution will be found in boosting and retaining the airline's passenger satisfaction. 


\subsection{Literature Review}

\subsection{Customer relationship management (CRM)}

In a fiercely competitive and economically demanding environment, airlines today are struggling to gain market share and sustain profitability. To do this, the airlines must develop new ways to manage their customer relationships to optimize customer loyalty and revenues, with mobile devices and ubiquitous Internet access having led to a dramatic evolution in the travel customer's experience, allowing for greater personalization and the expectation of real-time, up-to-date information about every aspect of their trip (TIBCO, 2017).

Often a profit center for airlines, CRM platforms are often viewed as nothing more than a frequent flyer program (FFP), with FFPs having been proven to be highly effective, with high cash generation ability (Agrawal, 2013). However, FFPs are now shifting the focus from customer satisfaction to revenue optimization within the airline industry, and the turning of FFPs and their CRM process into profit centers (Agrawal, 2013). A close look at many airlines also shows that although they have created vast amounts of passenger data obtained from their interactions with their passengers, the airlines are far behind in applying 'big data' in designing comprehensive CRM programs and strategies. Often times, they lose control of their data as airlines 'outsource' their CRM process to global distribution systems (GDSs) and online travel agencies (OTAs), which have driven a wedge between airlines and their customers (TIBCO, 2017).

However, CRM should be viewed as a competitive strategy that addresses the needs of consumers and integrates the way they interact with the organization (Larentis, Antonello and Slongo, 2018). CRM should also be a streamlined business process that delivers value to customers, employees, and stakeholders (Grant, 2017). The core concept of CRM should be focused on maintaining an existing customer base, by building relationships with customers in various ways.

Also, today, there has been a convergence of social media and CRM, which is creating both pitfalls and opportunities (Malthouse et al., 2013). Even today, the new field of social CRM is being investigated and how it affects this new frontier in marketing (Goldenberg, 2015).

Once again, social CRM is being discussed in terms of a value creation process, where big data and millions of customers are brought into the process. At its core, these new CRM tools should create a simple user interface that allows for the collection of data that helps businesses recognize and communicate with customers in a scalable way (Kulpa, 2017).

Therefore, after a review of the relevant literature and theory related to customer relationship management (CRM), the following four observed variables were included in the research. These included service quality ( $\mathrm{x} 1)$, customer-focused strategy ( $\mathrm{x} 2)$, product image ( $\mathrm{x} 3)$, and customer relationship management $(\mathrm{x} 4)$. Finally, the following three hypotheses were conceptualized for the research:

$\mathrm{H1}$ : Customer relationship management (CRM) has a direct positive influence on perceived service quality (PS).

$\mathrm{H} 2$ : Customer relationship management (CRM) has a direct influence on passenger trust (PT).

H3: Customer relationship management (CRM) has a direct influence on passenger satisfaction (PS).

\subsection{Perceived risk (PR)}

In early research about customer PR, Cox (1967) indicated that getting to know the nature and range of the PR by a consumer enables a better understanding of some of the aspects of consumer behavior. Jacoby and Kaplan (1972) also reported that many researchers had utilized the construct of PR to investigate various aspects of consumer behavior, with five primary types of PR being identified. These included financial, performance, physical, psychological, and social risk. Subsequently, a sixth PR was added by Roselius (1971, p. 58), in which time loss was added.

In a study on 776 Iranian airline passengers, it was also determined that service quality, relationship marketing, and brand image are related to a passenger's PR. Also, a strong negative correlation was found between the PR and the passenger's satisfaction (Ghotbabadi, Feiz and Baharun, 2016). This is consistent with Cho, Bonn, and Kang (2014), which reported that the increment of service quality and information quality could effectively decrease the consumer's perceptions of risk. In particular, airline passengers regard safety as the most critical reason when choosing a carrier (Gilbert and Wong 2003). Furthermore, it 
has been well established that customers' PR generally lowers their satisfaction (Johnson, Sivadas and Garbarino 2008).

Furthermore, Schiffman and Wisenblit (2015) stated that customers must find ways to reduce the risk of feeling empathetic when making a purchase decision and using the service. Also, Chen and Chang (2013) in research conducted in Taiwan, indicated that investing resources in the increase of green perceived quality and the decrease of green perceived risk is used to enhance green satisfaction and green trust.

Therefore, after a review of the relevant literature and theory related to perceived risk (PR), the following three observed variables were included in the research. These included information perception $(\mathrm{x} 5)$, perceived risk of service (x6), and privacy perception (x7). Finally, the following two hypotheses were conceptualized for the research:

H4: Perceived risk (PR) has a direct influence on passenger trust (PT).

H5: Perceived risk (PR) has a direct influence on passenger satisfaction (PS).

\subsection{Perceived service quality (PSQ)}

Byun, Lee, and Rye (2014) have reported that airline services are made up of both tangible and intangible properties, with service quality has become a significant strategic value in achieving a genuine and sustainable LCC competitive advantage in a global marketplace (Curry and Gao, 2012).

In Turkey, Pakdil and Aydin (2007) used the SERVQUAL Model to measure airline service quality and determined that responsiveness was most important. It was also noted that airlines needed to listen to the 'voice of the customer.' This was consistent with Amiruddin (2013), which also used the SERVQUAL model to measure tangibles, reliability, responsiveness, assurance, and empathy on Malaysia's AirAsia price, service quality, and customer loyalty.

Another component of service quality is reliability, which Baker (2014) defined as the ability to correctly provide the customers with services as promised without any assistance. Reliability can also be described as the ability to perform service dependably and accurately, such as punctuality, the efficiency of the check-in process, and convenience and accuracy of reservations and ticketing (Kim and Lee, 2011). This is consistent with consumer decision theory which suggests that consumers likely choose products or services based on behavioral and attitude factors, not just price (Blythe, 2013).

Another factor is tangibles, which are the physical equipment, facilities, personnel, and communication devices, and with LCCs, tangibles have been shown to be of the utmost importance (Kim and Lee, 2011), as well as customer responsiveness, which is the ability to serve and help passengers quickly. This is also consistent with a study of 1,212 Thai LCC passengers in which it was determined that the most critical dimension of service quality was flight schedules. This was followed by the quality of the LCC's flight attendants, airport and aircraft tangibles, and the ground staff (Saha, 2009).

Various other studies have also identified other factors as key to airline passenger repurchase intention. One such component is reliability, which Baker (2014) defined as the ability to provide passengers with services as promised. Reliability can also be described as the ability to perform service dependably and accurately. Reliability includes punctuality, the efficiency of the check-in process, and convenience and accuracy of reservations and ticketing (Kim and Lee, 2011).

Therefore, after a review of the relevant literature and theory related to perceived service quality (PSQ), the following three observed variables were included in the research. These included reliability (y7), assurance (y8), and tangibility (y9). Finally, the following hypothesis was conceptualized for the research: H6: Perceived service quality (PS) has a direct influence on passenger trust (PT).

\subsection{Passenger trust (PT)}

Morgan and Hunt (1994) stated that trust plays a significant role in determining commitment between customers and companies. Furthermore, Chaudury and Holobrook (2001), reported that trust is essential to organizational effectiveness. The positive effects of work are the result of increased trust within the organization, resulting in increased employee productivity and organizational commitment (Nyhan and Marlowe, 1997). Trust is the basis of communication relationships in providing services to customers, with customer trust having a direct influence on customer loyalty (Marakanon and Panjakajornsak, 2017). 
This is consistent with Haryono et al. (2015) which studied full-service carrier (FSC) passenger characteristics at the Adisutjipto International Airport Yogyakarta (JOG) in Java, Indonesia, and determined that service quality has a significant effect on trust, customer satisfaction, customer delight, and repurchase intention.

Therefore, after a review of the relevant literature and theory related to passenger trust (PT), the following three observed variables were included in the research. These included safety confidence (y1) management confidence (y2), and performance confidence (y3). Finally, the following final hypothesis was conceptualized for the research:

H7: Passenger trust (PT) has a direct influence on passenger satisfaction (PS).

\subsection{Passenger satisfaction (PS)}

In Malaysia, Munusamy, Chelliah and Pandian (2011) developed some interesting insights concerning their research on AirAsia's passenger satisfaction. Although in the past price had been viewed as the most critical thing for an LCC such as AirAsia, as the airline has evolved and matured, passengers have come to expect more for their money. These factors now include pre-flight services, CRM, the cabin environment, and in-flight services. This is also consistent with Heracleous and Wirtz (2010), which reported that carriers who wish to be successful must focus on passenger services, which includes efficiency, reliability, confidence in the staff, and personal attention.

A consumer's expectation about an organization's services acts as a standard for the performance evaluation of that organization, with customers comparing their organization's performance expectation with the service offered. Furthermore, CRM can be improved through better analysis of the consumer's expectation of these services (Olshavsky and Kumar, 2001). Also, customer satisfaction is the outcome felt by those that have experienced a company's performance that has fulfilled their expectations (Angelova and Zekiri, 2011). Research on a Dubai FSC airline suggested service quality, perceived value, and brand image have a significant positive impact on customer satisfaction, which leads to brand loyalty (Hussain, Nasser, and Hussain, 2015).

According to a study on airline passengers by Ringle, Sarstedt and Zimmermann (2011), perceived safety was a critical driver in explaining the degree of overall customer satisfaction. This is consistent with airline research from Zins (2001), in which it was determined that corporate image, service quality, and customer satisfaction are powerful and illustrative components for explaining future customer loyalty. It must be remembered that even a small increase in customer retention produced a dramatic and positive effect on profitability (Reichheld and Sasser, 1990).

Therefore, after a review of the relevant literature and theory related to passenger satisfaction (PS), the following three observed variables were included in the research. These included service quality satisfaction (y4), value for money (y5), and professional response (y6). From the review of the literature and theory, the conceptual model for the study is presented in Figure 1.

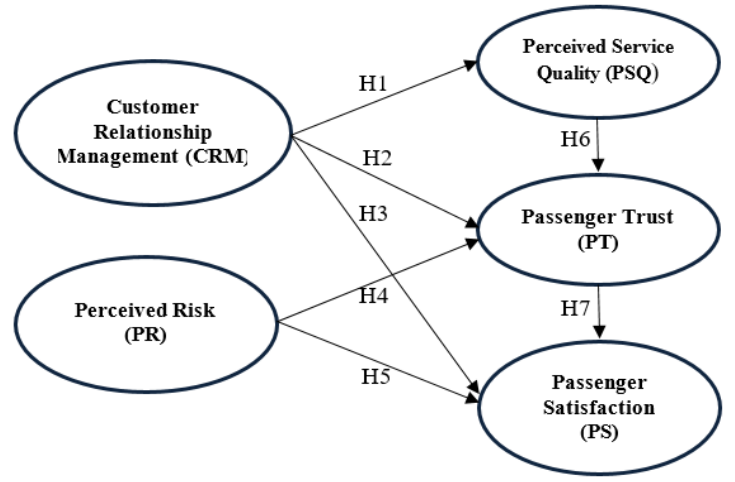

Figure 1. The conceptual model for Thai Airways passenger satisfaction (PS).

\subsection{Study objectives}

The purpose of this study is to develop a passenger satisfaction model and empirically test its underlying constructs in the Thai and Asian aviation sector. 
To study the interrelationships between perceived service quality (PSQ), customer relationship management (CRM), passenger trust (PT), and perceived risk (PR) on Thai Airways passenger satisfaction (PS).

\subsection{Methods}

\subsection{Population and sample}

A team of Thai university students was used to obtain survey information from a sample of 565 passengers who were boarding Thailand's nationally flagged, full-service carrier (FSC), Thai Airways at Suvarnabhumi Airport from May to July 2014. As the Thai Airways passenger list was not available for public use, systematic sampling techniques were used by selecting every $5^{\text {th }}$ check-in passenger.

Using a formula from Levine, Berenson, and Krehbiel (2011), the required sample size was determined. Confirmation that 565 was highly reliable was also indicated by statistical sampling requirements from Krejcie and Morgan (1970), whose table of required sample sizes indicates that as the population increases, the sample size increases to approximately 380 cases at a diminishing rate (plateau).

\subsection{Qualitative research}

Furthermore, during the period between May to July 2014, qualitative research was further conducted by use of in-depth, semi-structured, guided interviews with five individuals including three Thai university professors, and two Thai Airways executive managers. Their input covered PS, CRM, PT, PR, and PS. For the study, Cronbach's alpha (Tavakol and Dennick, 2011) was used to evaluate the initial 30 samples which used a 7-level, Likert scale (Matell and Jacoby, 1972), with '7' indicating 'strongly agree' and ' 1 ' indicating 'very low opinion.' The value of alpha (a) that is considered acceptable usually is 0.70 or higher (Hair, Hult, Ringle, and Sarstedt, 2016).

\subsection{Research tool}

For this study, the authors used a descriptive survey methodology designed to assess how well passengers were satisfied when they flew with Thailand's national FSC Thai Airways. The design employed the self-administration of a 41-item questionnaire to 565 passengers which was aimed at finding each's attitudes and opinion about how the study's 16 observed variables impacted PS. Using the guidelines of Best and Kahn (2003), the questionnaires collected from the 565 individuals indicated that the overall survey average was 'I more agree,' with an average of 5.66 overall. Furthermore, the survey's questionnaire utilized was divided into two sections (Matell and Jacoby, 1972). Part 1 consisted of seven items relating to the passengers' travel characteristics (Table 1), while Part 2 was divided into seven sections with 34 items concerning PSQ, CRM, PR, PT, and PS.

\subsection{Confirmatory factor analysis (CFA)}

The CFA was conducted using the LISREL 9.1 software program, which indicated that the value of $\chi 2$ was not statistically significant $(p>0.05)$. with the $\chi^{2} / \mathrm{df}<2.00$. Convergence validity was also adapted to measure the factor loadings of the observed variables and latent variables. Hooper, Coughlan, and Mullen (2008) discussed low $\mathrm{R}^{2}$ values $(\leq 0.20)$, and suggested that they are removed from the analysis, as this is an indication of high error rates. All factor loadings, however, showed values $>0.5$ (Fornell and Larcker, 1981). The reliability of each construct was also examined through CFA by using the composite reliability $(C R>0.6)$ to measure the internal consistency of a single construct (Kline, 2011). Afterward, the validity of the model fit was also tested by using the average variance extracted (AVE). Also, the comparative fit index (CFI) was used which had a criterion of $\geq .95$, a standardized root mean square residual $(\mathrm{SRMR}) \leq 0.05$, and a root mean square error of approximation (RMSEA) as a measure of goodness-of-fit (GOF) in the models (Kline, 2011), as well as to measure the discrepancy per degree of freedom (Hu and Bentler, 1999).

\subsection{Results}

\subsection{Passenger's Response Information}

Table 1 shows that the mean scores and standard deviation of the factors that affect Thai Airways passenger satisfaction (PS). The latent variables from the survey included CRM, PR, PSQ, PT, and PS. Interpreted results from the 7-point survey ranged from 4.14- 5.83 (Best and Kahn, 2003). 


\begin{tabular}{|c|c|c|c|c|}
\hline Latent Variable & Items & $\bar{x}$ & S.D. & Level \\
\hline Customer Relationship Management (CRM) & 8 & 5.83 & .45 & I more agree \\
\hline Perceived Risk (PR) & 6 & 5.60 & .41 & I more agree \\
\hline Perceived Service Quality (PSQ) & 6 & 5.84 & .42 & I more agree \\
\hline Passenger Trust (PT) & 7 & 5.29 & .34 & I agree \\
\hline Passenger Satisfaction (PS) & 7 & 5.76 & .35 & I more agree \\
\hline Total/Averages & 34 & 5.66 & .32 & I more agree \\
\hline
\end{tabular}

Table 1: Mean and Standard Deviation of Thai Airways Passenger Survey Interpretation Note. $\overline{\mathrm{x}}=$ the standard mean, S.D. $=$ Standard Deviation.

\subsection{Thai Airways passengers' descriptive analysis $(n=565)$}

For personal data (Table 2), it was found that $62.83 \%$ of the passengers were male, while $37.17 \%$ were female. A slight majority or $25.66 \%$ were between $35-44$ years old. Also, a significant number reported that they were Asian (44.60\%), with most indicating they were traveling on holiday (55.93\%).

\begin{tabular}{|c|c|c|}
\hline Item & Passengers & $\%$ \\
\hline \multicolumn{3}{|l|}{ Gender } \\
\hline male & 355 & 62.83 \\
\hline female & 210 & 37.17 \\
\hline Total & 565 & 100.00 \\
\hline \multicolumn{3}{|l|}{ Age } \\
\hline Less than 25 years old. & 16 & 2.83 \\
\hline $25-34$ years old. & 90 & 15.93 \\
\hline $35-44$ years old. & 145 & 25.66 \\
\hline 45-54 years old. & 130 & 23.01 \\
\hline 55-64 years old. & 108 & 19.12 \\
\hline 65 years or older. & 76 & 13.45 \\
\hline Total & 565 & 100.00 \\
\hline \multicolumn{3}{|l|}{ Ethnicity } \\
\hline Asian & 252 & 44.60 \\
\hline European & 102 & 18.05 \\
\hline North American & 46 & 8.14 \\
\hline Middle Eastern & 89 & 15.75 \\
\hline Other & 76 & 13.45 \\
\hline Tota1 & 565 & 100.00 \\
\hline \multicolumn{3}{|l|}{ Travel Purpose } \\
\hline Leisure/Holiday & 316 & 55.93 \\
\hline Business & 231 & 40.88 \\
\hline Other & 18 & 3.19 \\
\hline Tota1 & 565 & 100.00 \\
\hline \multicolumn{3}{|l|}{ Profession } \\
\hline Business person & 189 & 33.45 \\
\hline Professional & 176 & 31.15 \\
\hline Service Provider & 135 & 23.89 \\
\hline Freelance / other & 65 & 11.50 \\
\hline Total & 565 & 100.00 \\
\hline \multicolumn{3}{|l|}{ Number of days } \\
\hline $1-3$ & 41 & 7.26 \\
\hline $4-6$ & 144 & 25.49 \\
\hline $7-9$ & 203 & 35.93 \\
\hline $10-12$ & 109 & 19.29 \\
\hline Over 12 days & 68 & 12.04 \\
\hline Total & 565 & 100.00 \\
\hline Average cost per day & \$US187.12 & \\
\hline
\end{tabular}

Table 2: Personal Characteristics of Thai Airways Passenger Respondents $(n=565)$

\subsection{Confirmatory factor analysis (CFA) results}

This study's CFA was based on the theoretical relationships between the 16 observed and unobserved variables, which are responses to statements from the Likert-based scale. LISREL 9.1 software was used to analyze the confirmatory components, which determined that $\chi 2$ was not statistically significant $(p>0.05), \chi 2 / \mathrm{df}$ was $<2.00$, RMSEA $<0.05$, and SRMR $<0.05$. Furthermore, from Tables 3 and 4 , $\alpha$ was shown to range from 0.70 to 0.81 and CR was from 0.61 to 0.79 . Hair et al. (2016) has also indicated that $R^{2}$ values of 0.75 are significant, 0.50 are in the middle, and 0.25 are very weak. 


\begin{tabular}{|c|c|c|c|c|c|c|}
\hline constructs & $\alpha$ & CR & AVE & Observed variables & loading & $\mathbf{R}^{2}$ \\
\hline \multirow{4}{*}{$\begin{array}{l}\text { Customer } \\
\text { Relationship } \\
\text { Management } \\
\text { (CRM) }\end{array}$} & \multirow[t]{4}{*}{0.70} & \multirow[t]{4}{*}{0.81} & \multirow[t]{4}{*}{0.52} & service quality $(\times 1)$ & 0.82 & 0.67 \\
\hline & & & & customer-focused strategy $(\times 2)$ & 0.70 & 0.49 \\
\hline & & & & product image $(\times 3)$ & 0.66 & 0.44 \\
\hline & & & & $\begin{array}{l}\text { customer relationship } \\
\text { management }(x 4)\end{array}$ & 0.68 & 0.47 \\
\hline \multirow{3}{*}{$\begin{array}{l}\text { Perceived } \\
\text { Risk (PR) }\end{array}$} & \multirow[t]{3}{*}{0.81} & \multirow[t]{3}{*}{0.75} & \multirow[t]{3}{*}{0.51} & information perception $(x 5)$ & 0.93 & 0.86 \\
\hline & & & & perceived risk of service $(\times 6)$ & 0.66 & 0.43 \\
\hline & & & & privacy perception $(x 7)$ & 0.49 & 0.37 \\
\hline
\end{tabular}

Table 3: Confirming Elements of External Latent Variables

\begin{tabular}{|c|c|c|c|c|c|c|}
\hline constructs & $\alpha$ & $\mathrm{CR}$ & AVE & Observed variables & loading & $R^{2}$ \\
\hline \multirow{3}{*}{$\begin{array}{l}\text { Perceived } \\
\text { Service } \\
\text { quality (PSQ) }\end{array}$} & \multirow[t]{3}{*}{0.70} & \multirow[t]{3}{*}{0.89} & \multirow[t]{3}{*}{0.74} & reliability (y7) & 0.73 & 0.65 \\
\hline & & & & assurance (y8) & 0.83 & 0.73 \\
\hline & & & & tangibility (y9) & 0.56 & 0.32 \\
\hline \multirow{3}{*}{$\begin{array}{l}\text { Passenger } \\
\text { Trust (PT) }\end{array}$} & \multirow[t]{3}{*}{0.79} & \multirow[t]{3}{*}{0.75} & \multirow[t]{3}{*}{0.50} & safety confidence (y1) & 0.70 & 0.49 \\
\hline & & & & $\begin{array}{l}\text { management } \\
\text { confidence }(\mathrm{y} 2)\end{array}$ & 0.77 & 0.59 \\
\hline & & & & $\begin{array}{l}\text { performance } \\
\text { confidence }(\mathrm{y} 3)\end{array}$ & 0.64 & 0.41 \\
\hline \multirow[t]{3}{*}{$\begin{array}{l}\text { Passenger } \\
\text { Satisfaction } \\
\text { (PS) }\end{array}$} & \multirow[t]{3}{*}{0.75} & \multirow[t]{3}{*}{0.73} & \multirow[t]{3}{*}{0.47} & $\begin{array}{l}\text { service quality } \\
\text { satisfaction (y4) }\end{array}$ & 0.63 & 0.40 \\
\hline & & & & value for money $(\mathrm{y} 5)$ & 0.63 & 0.40 \\
\hline & & & & $\begin{array}{l}\text { professional response } \\
\text { (y6) }\end{array}$ & 0.7 & 0.63 \\
\hline
\end{tabular}

Table 4: Confirming Elements of Internal Latent Variables

\subsection{Convergent Model Analysis}

From the LISREL 9.1 analysis of the data, and the measurement of the five latent variables and their related hypotheses, it was determined that there was a good model fit with the empirical research data. Construct validity uses both convergent and discriminant validity in combination and must be used together to establish overall validity. Convergent validity can be analyzed in three ways. These include item reliability, composite reliability (CR), and average variance extracted (AVE) (Chau, 1997). As such, to assess the validity of the study's models, convergent validity and discriminant validity were used. Also, in SEM, a CFA is usually used to access construct validity (Jöreskog, Olsson, and Fan, 2016). Hair et al. (2016) and Byrne, Shavelson, and Muthén (1989) have also indicated that factor loadings or regression weight estimates of latent to observed variables should have values higher than 0.50 .

The first measure, item reliability is indicated if items have significant factor loadings of 0.50 or above. The second measure, composite reliability, is assessed based on the criteria that the indicator's estimated pattern coefficient is significant for its underlying factor, which should have a threshold value for construct reliability at 0.60 or higher, with all AVE values higher than 0.50 (Hair et al., 2016).

Results in Table 5 show that the $\chi 2$ value was 16.68, which had 17 degrees of freedom (df). Therefore, the ratio between $\chi 2$ and the $\mathrm{df}$ was equal to 0.98 when tested, which showed no statistical significance as it was $\geq 0.05$, which confirms the model's hypotheses are not different from the empirical data. Further confirmation was established as the results of the GFI $=0.99$, and the AGFI $=0.97$. The CFI was equal to 1.00 . The RMSEA was equal to 0.000 . The SRMR was equal to 0.02 , which indicates an excellent fit as its value < 0.05 (Hu and Bentler, 1999). 


\begin{tabular}{|lcccl|}
\hline Criteria Index & Criteria & Values & Results & \multicolumn{1}{c|}{ Supporting theory } \\
\hline Chi-square: $\chi^{2}$ & $p \geq 0.05$ & 16.68 & passed & Rasch, 1980 \\
Relative Chi-square: $\chi 2 / \mathrm{df}$ & $\leq 2.00$ & 0.98 & passed & Byrne et al.,1989 \\
GFI & $\geq 0.90$ & 0.99 & passed & Jöreskog et al., 2016. \\
AGFI & $\geq 0.90$ & 0.97 & passed & Hooper et al., 2008 \\
SRMR & $\leq 0.05$ & 0.02 & passed & Hu and Bentler, 1999 \\
RMSEA & $\leq 0.05$ & 0.00 & passed & Hu and Bentler, 1999 \\
CFI & $\geq 0.90$ & 1.00 & passed & Schumacker and Lomax, 2010 \\
Cronbach's Alpha $(\alpha)$ & $\geq 0.70$ & $0.70-0.81$ & passed & Tavakol and Dennick, 2011 \\
\hline
\end{tabular}

Table 5: Criteria and Theory of the Values of Goodness-of-Fit Appraisal.

The validated results are detailed in Table 7 and Table 8, as well as the hypotheses testing results shown in Figure 2.

\begin{tabular}{|llllll|}
\hline Variables & CRM & PR & PSQ & PT & PS \\
\hline CRM & 1 & & & & \\
PR & $.64^{* *}$ & 1 & & & \\
PSQ & $.66^{* *}$ & $.64^{* *}$ & 1 & & \\
PT & $.31^{* *}$ & $.61^{* *}$ & $.32^{* *}$ & 1 & \\
PS & $.59^{* *}$ & $.67^{\star *}$ & $.70^{* *}$ & $.49^{* *}$ & 1 \\
\hline$\rho \mathrm{\rho V}$ (AVE) & 0.55 & 0.41 & 0.57 & 0.50 & 0.51 \\
\hline$\rho \mathrm{\rho c}$ (Construct & 0.83 & 0.67 & 0.80 & 0.74 & 0.76 \\
Reliability) & & & & & \\
AVE & 0.74 & 0.64 & 0.75 & 0.71 & 0.71 \\
\hline
\end{tabular}

Table 6: Correlation Coefficients between Latent Variables (under the diagonal) Construct Reliability $(\rho C)$ and the Average Variance Extracted (AVE)

Note: AVE is shown on the diagonal of the matrix (in bold). Square of inter-construct correlation is shown under the diagonal. ${ }^{*}$ Sig. $<.01$.

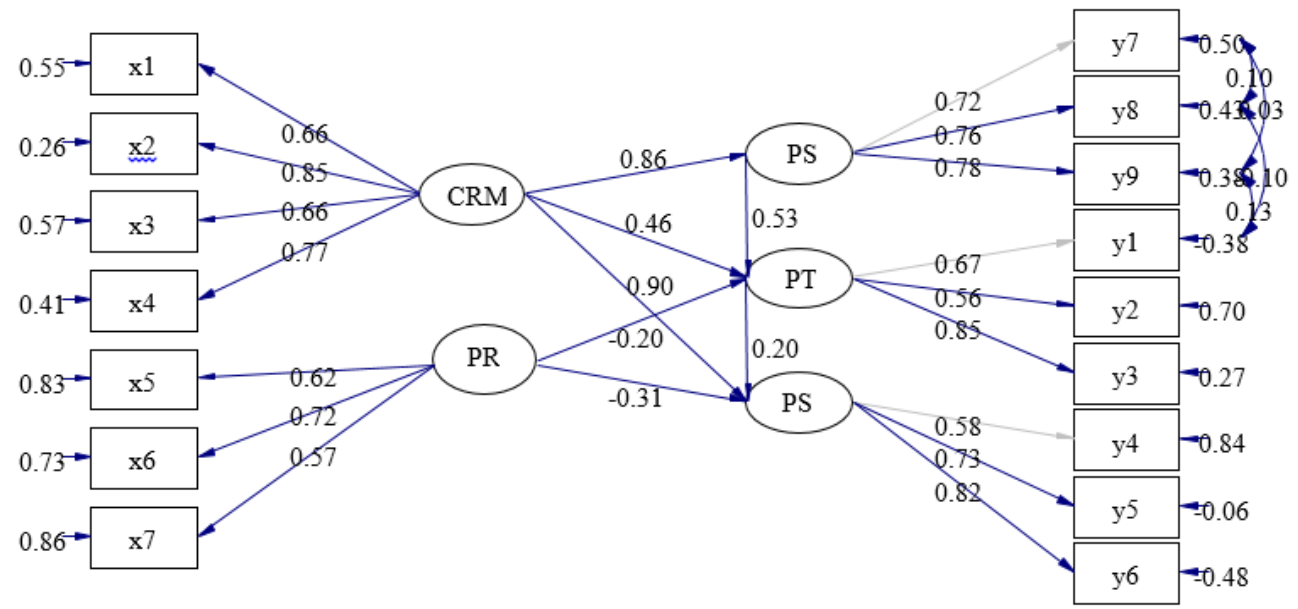

Figure 2. SEM of variables affecting Thai Airways passenger satisfaction (PS)

Note. Chi-Square $=16.68, \mathrm{df}=17, p$-value $=0.47630$, RMSEA $=0.000$

Additionally, the direct effect (DE), indirect effect (IE), and total effects (TE) of the latent variables on Thai Airways passenger satisfaction (PS) are shown in Table 7. 


\begin{tabular}{|c|c|c|c|c|c|c|}
\hline \multirow{2}{*}{$\begin{array}{l}\text { Dependent } \\
\text { variables }\end{array}$} & \multicolumn{6}{|c|}{ Independents } \\
\hline & & $R^{2}$ & PT & PSQ & PR & CRM \\
\hline \multirow{3}{*}{ PS } & $\mathrm{DE}$ & \multirow{3}{*}{.14} & $0.20^{*}$ & - & $-0.31^{\text {** }}$ & $0.90^{\text {kk }}$ \\
\hline & IE & & - & 0.11 & -0.04 & $0.10^{*}$ \\
\hline & $\mathrm{TE}$ & & $0.20^{*}$ & 0.11 & $-0.35^{\star \star \star}$ & $1.00^{\text {kik }}$ \\
\hline \multirow{3}{*}{ PT } & $\overline{\mathrm{DE}}$ & \multirow{3}{*}{.38} & & $0.53^{\text {k*k }}$ & $-0.20^{* \star k}$ & $0.46^{\text {kk }}$ \\
\hline & IE & & & - & - & $0.45^{\text {kผ }}$ \\
\hline & TE & & & $0.53^{\text {**k }}$ & $-0.20^{\text {*k }}$ & $0.91^{* * *}$ \\
\hline \multirow{3}{*}{ PSQ } & $\mathrm{DE}$ & \multirow{3}{*}{.74} & & & & $0.86^{\text {*k }}$ \\
\hline & IE & & & & & - \\
\hline & TE & & & & & $0.86^{\text {k*k }}$ \\
\hline
\end{tabular}

Table 7: Standard Coefficients of Influence in the SEM of the Variables Affecting PS Note. *Sig. $<0.05, * *$ Sig. $<0.01$.

A latent variable path analysis was performed using LISREL 9.1 software, with the models found to be consistent with empirical data. The causal factors in the model had both a positive and negative influence on Thai Airways passenger satisfaction (PS), which can be explained by $14 \%$ of the variance $\left(R^{2}\right)$. $\mathrm{R}$-squared shows the percentage of the dependent variable variation that a linear model explains (Frost, 2017).

$$
R^{2}=\frac{\text { Variance explained by the model }}{\text { Total variance }}
$$

The four variables ranked in importance included customer relationship management (CRM), perceived risk (PR), passenger trust (PT), and perceived service quality (PSQ), which had a total effect (TE) value of $1.00,-0.35,0.20$ and 0.11 , respectively. Results of the hypotheses testing are shown in Table 8.

\begin{tabular}{|c|c|c|c|}
\hline Hypotheses & Coef. & t-test & Results \\
\hline $\begin{array}{l}\text { H1: Customer relationship management (CRM) has } \\
\text { a direct influence on perceived service quality } \\
\text { (PSQ). }\end{array}$ & 0.86 & $19.45^{\star \star \star}$ & consistent \\
\hline $\begin{array}{l}\text { H2: Customer relationship management (CRM) has } \\
\text { a direct influence on passenger trust (PT). }\end{array}$ & 0.46 & $3.67^{k * k}$ & consistent \\
\hline $\begin{array}{l}\text { H3: Customer relationship management (CRM) has } \\
\text { a direct influence on passenger satisfaction (PS). }\end{array}$ & 0.90 & $5.95^{\text {k* }}$ & consistent \\
\hline $\begin{array}{l}\mathrm{H} 4: \text { Perceived risk (PR) has a direct influence on } \\
\text { passenger trust }(\mathrm{PT}) \text {. }\end{array}$ & -0.20 & $3.19^{k \cdots k}$ & consistent \\
\hline $\begin{array}{l}\text { H5: Perceived risk (PR) has a direct influence on } \\
\text { passenger satisfaction (PS). }\end{array}$ & -0.31 & $3.07^{k \cdots k}$ & consistent \\
\hline $\begin{array}{l}\text { H6: Perceived service quality (PSQ) has a direct } \\
\text { influence on passenger trust (PT). }\end{array}$ & 0.53 & $3.79^{k \cdots k}$ & consistent \\
\hline $\begin{array}{l}\text { H7: Passenger trust (PT) has a direct influence on } \\
\text { passenger satisfaction (PS). }\end{array}$ & 0.20 & $2.40^{*}$ & consistent \\
\hline
\end{tabular}

Table 8: Results of the Hypothesis Testing

\subsection{Discussion}

“The liberalization of ASEAN's aviation sector will be a major catalyst for the region's economic growth by 2030" - Liow Tiong Lai, Malaysian Minister of Transport (Dupont, 2015)

The Malaysian Minister of Transport's thoughts are backed by strong arguments as aviation plays a vital role in developing business, trade, sales, innovation, investments and tourism, all facilitating economic growth (Dupont, 2015). In recent times, the quality of life of air transportation services (ATS) has always been one of the predominant factors that determine a nation's economic progress. Therefore, a well-managed ATS serves as a catalyst for economic transformation (Kumudha and Bhunia, 2016). In Thailand, commercial aviation statistics are particularly impressive, as in 2016122 million passengers transited a Thai AOT (Airports of Thailand) operated airport (Kositchotethana, 2017). According to Ringle et al. (2011), when investigating the quality of a SEM, the target constructs' percentage of variance explained $\left(R^{2}\right)$ is a key criterion, which is a goodness-of-fit measure and indicates the percentage of the 
variance in the dependent variable that the independent variables explain collectively (Frost, 2017). As such, based on the results of the study's SEM variables affecting Thai Airways passenger satisfaction (PS), it was found that the causal factors in the model had both a positive and negative influence, which can be explained by the $14 \%$ of the variance in PS $\left(R^{2}\right)$. The variables ranked in importance included CRM, PR, PT, and PSQ, which had a total value of $1.00,-0.35,0.20$ and 0.11 , respectively.

\subsection{Customer relationship management (CRM)}

From the study, CRM in $\mathrm{H} 1, \mathrm{H} 2$, and $\mathrm{H} 3$ was determined to have a direct influence on PSQ, PT, and PS, with TE scores of $0.86,0.91$, and 1.00, respectively. This shows the crucial importance of CRM is to an airline's success. Supporting this was research from Larentis et al. (2018) which investigated organizational culture and relationship marketing (RM) and stated that RM aims to generate long-term profitable relationships between partners. As such, far too many airlines have equated their CRM process with their frequent flyer program (FFP). Instead, airlines should use CRM to segment their passengers, be responsive to their needs and desires, and instill a service focused mentality in their employees. Furthermore, by use of CRM airline staff will have a better overview of the passenger. This is consistent with Krämer, Tachilzik and Bongaerts (2017) and Wan (2017), which reported that an airline's digital behavior and the associated technological environment, are increasingly having a significant impact on the way companies manage their customer relationships. Also, CRM is a competitive strategy, and the focus needs to be given to consumers. It is also a business process improvement that delivers value to customers, employees, and stakeholders.

These factors were in agreement with this study's results as well, as CRM was judged overwhelmingly to be of critical importance to a Thai Airway's passenger satisfaction. This is in agreement with Ringle et al. (2011) which summarized that knowing a passenger's travel purpose can be used to target market segments more efficiently. Examples include emphasizing the airline's safety when it comes to pleasure travelers while focusing on improving in-flight elements, such as seating comfort, for business travelers (Munusamy et al., 2011).

Vuthisopon and Srinuan (2017) also discussed the impact of E-Service Quality (ESQ) within the Thai LCC airline sector and reported that when customers book seats online, confirmation messages should be sent to their mobile phones automatically. Also, channels of payment should be increased, airline office online hours' contact should be extended in order that customers can contact the LCC office at any time, and in the case of problems or delays in check-in, solutions must be found quickly in order to increase competence in services and LCC competitiveness.

However, e-commerce vendors using online systems need to convince their customers that both the vendors and systems are trustworthy (Järveläinen, 2007). This is consistent airline e-ticketing research from Lau, Kwek and Tan (2011), which indicated that airline e-ticketing was comprised of five variables, including ease of use, website design, assurance, responsiveness, and personalization.

\subsection{Perceived risk (PR)}

From the study, both $\mathrm{H} 4$ and $\mathrm{H} 5$ were found to have both direct and indirect negative influences on PT $($ TE $=-0.20)$ and PS $(-0.35)$, respectively. From the study on Thai Airways passenger satisfaction, PR has a mean score of 5.60. This is because PR is the ability to assess the risk that consumers face in decisionmaking (Kotler and Armstrong, 2002). Therefore, knowledge of the sources and character of consumer PR is of great importance for companies. Schiffman and Kanuk (2015), also reported that the scale and type of consumer reaction depend on the perceived level of risk, and on his or her level of tolerance for the perceived risk. Chang and Chen (2008), also argued that a reduction in PR leads to an increase in purchase probability. Therefore, a decrease in PR helps in increasing PS. Vuthisopon and Srinuan (2017) determined that two of the most important things for an LCC airline was airline security standards and services on board. Johnson et al. (2008) also concluded that commitment has a positive influence on customer satisfaction, which diminishes risk perceptions.

\subsection{Perceived service quality (PSQ)}

The study also determined that PSQ (H6) had a direct influence on PT (TE = 0.53). It was also determined that PSQ has a positive and indirect effect on Thai Airways passenger satisfaction $(\mathrm{TE}=11)$. Reasons for the high importance placed by Thai Airways passengers' on PSQ is that it is a comparison 
between the customer's expectations in the product or service and their actual perception (Ali, 2018). If the customer or customer sees that the product or service is the best and meets the expectations, they will continue to use it (Hutchins, 1985, p.165; Juran and Gryna, 1998; Zeithaml, Parasuraman and Berry, 1990, p.16). This is consistent with Chou, Liu, Huang, Yih, and Han (2011), which viewed airline service quality in Taiwan as a key to a successful airline.

Multiple studies have also reported that passenger service quality satisfaction is contingent on how an airline responds to passenger needs (Lerrthaitrakul and Panjakajornsak, 2014). Furthermore, Moreover, past passenger perceptions concerning service quality satisfaction could significantly influence a passenger's decision when choosing the same airline again (Park, Robertson and $\mathrm{Wu}, 2004$; Yang, Hsieh and Yang, 2012).

In Hong Kong, Gilbert and Wong (2003) discovered there were significant differences among passengers of different ethnic groups/nationalities, as well as among passengers who travel for business, for a holiday, or to visit their family. Additionally, these Asian travelers consistently ranked 'assurance' as the most important service dimension, with passengers concerned about safety and security. This is consistent with this study's survey of Thai Airways passengers in which the section concerning PSQ had an overall mean score of 5.84, the highest section rank within the survey. Additionally, Gefen (2002) discussed customer loyalty in e-commerce, using components of the RATER (SERQUAL) model, and determined that responsiveness, reliability, and assurance played vital roles.

\subsection{Passenger trust (PT)}

From the study, PT (H7) was determined to have a positive and direct influence on PS (TE=0.20), with the survey item of "You can count on Thai Airways to solve the problem," obtaining the highest mean passenger score (mean=5.76) from this category.

In a study on the Libyan airline industry, Ehbara and Shukor (2016) investigated service quality and customer trust and determined that there is a positive relationship between the service quality factors and customer trust, except when it came to employee competence. Shared values and benevolence of service quality factors were found to have high influences on customer trust. Additionally, other studies have confirmed that customer trust, attachment, integrity, and positive word of mouth, has a positive effect on customer loyalty (Ahrens, Coyle and Strahilevitz, 2013; de Villiers, 2015; Lai, 2015). Gregg and Walczak (2010) studied the relationship between site qualities, trust and price increase in online auctions, and reported that Web site quality is positively correlated with trust.

\subsection{Passenger satisfaction (PS)}

In the United States, Southwest Airlines has helped the airline industry achieve the highest level of airline customer satisfaction ever (JD Power, 2018). One key component in Southwest Airlines achieving the highest marks ever (818) for airline CS (JD Power, 2018), has been the airline's customer relation representatives CRM tools, which helps the airline's staff help make decisions on their own. The airline tries to be a one-stop shop where each CRM representative handles the passengers in a hurry and don't have to send them to another team or another department. Each CRM representative is trained in all systems, policies, how to speak to passengers, and on the different channels through which Southwest Airlines interacts with their customers (Telus International, 2017). Furthermore, from the 11,508 US airline passengers surveyed, the most important items in a passenger's satisfaction were (ranked in importance) cost and fees, in-flight services, aircraft, boarding/deplaning/baggage, flight crew, check-in, and the reservation system (JD Power, 2018).

This is consistent with the results from this study's survey on Thai Airways passengers in which the item 'Thai Airway's staff is professional' was given the highest mean score of 6.83. It is also consistent with the 2018 Skytrax awards for Thai Airways in which the airline was ranked first in the 'World's Best Economy Class' and 'Best Economy Class Onboard Catering' categories (Thai Airways, 2018). In-flight services, therefore, have become vital in passenger satisfaction. Airlines should also become aware of the value of safety and its influence on customer satisfaction and loyalty and treat it as an asset that should be better utilized in the future (Ringle et al., 2011). 


\subsection{Conclusion}

Within the airline industry, CRM has come into focus as airlines recognize the importance of effective customer management in establishing a long-term competitive advantage. CRM's promise is indeed compelling, as it strengthens airline passenger loyalty, which can lead to higher revenue, with lower customer acquisition costs, and an improvement in operational efficiency. For full-service airlines, CRM is an essential component of their corporate strategy, which viewed from the eyes of a passenger, means differentiating themselves from competitors.

\subsection{Limitations and Scope for Future Research}

This study was conducted on Thai Airways' passengers only from a single Bangkok airport. As such, there are limitations to the study and its conclusions. The authors have also noted from the research that there are significant differences in passenger perceptions about satisfaction when comparing LCCs and FSCs. Further research is, therefore, warranted in this area. As the study was focused on a single, FSC national carrier, there are limitations for the study's use to a broader industry (e.g. LCCs, South American airlines, etc.). This study also did not investigate how aircraft age and cabin appointments affects passenger satisfaction and retention, but they are excellent factors for future research. Additional factors open for investigations include how investing in Wi-Fi capability, terminal lounges, passenger digital platforms and ancillary products might improve passenger satisfaction. Also, consideration needs to be given into diversifying into new customer products, such as financial services and the health and wellness sector.

\section{References}

Agrawal, M. (2013). The ultimate guide to airline customer relationship management and loyalty.

Available at: https:/ / tinyurl.com/yarn699n [Accessed 1 Oct. 2018].

Ahrens, J., Coyle, J. R. and Strahilevitz, M. A. (2013). Electronic word of mouth: The effects of incentives on e-referrals by senders and receivers. European Journal of

Marketing, 47(7), pp. 1034 - 1051. Available at: doi: 10.1108/03090561311324192

Ali, Q. (2018). Service quality from customer perception: Comparative analysis between Islamic and conventional bank. Journal of Marketing and Consumer Research, 43, pp. 70 - 82. Available at: https://tinyurl.com/ybvutn5a [Accessed 1 Oct. 2018].

Amiruddin, N. H. (2013). Price, service quality and customer loyalty: A case study of AirAsia. South East Asia Journal of Contemporary Business, Economics and Law, 2(1). Available at: http://tinyurl.com/lhohoae [Accessed 1 Oct. 2018].

Angelova, B. and Zekiri, J. (2011). Measuring customer satisfaction with service quality using American Customer Satisfaction Model (ACSI Model). International Journal of Academic Research in Business and Social Sciences, 1(3), pp. 232 - 258. Available at: doi: 10.6007/ijarbss. v1i2.35

ASEAN Today. (2018). A potential remedy for Thailand's tourism woes. Available at: https:// tinyurl.com/yccxgyfj [Accessed 1 Oct. 2018].

Baker, D. A. (2013). Service quality and customer satisfaction in the airline industry: A comparison between legacy airlines and low-cost airlines. American Journal of Tourism Research, 2(1), pp. 67-77. Available at: doi: $10.11634 / 216837861302317$

Baker, D. (2014). Low-cost airlines management model and customer satisfaction. International Journal of Economics, Commerce, and Management, 2(9), pp. 1 - 17. Available at: http://tinyurl.com/jxg2ymb [Accessed 1 Oct. 2018].

Baker, D. (2014). Low-cost airlines management model and customer satisfaction. International Journal of Economics, Commerce, and Management, 2(9), pp. 1 - 17. Available at: http://tinyurl.com/jxg2ymb [Accessed 1 Oct. 2018].

Best, J. W. and Kahn, J. V. (2003). Research in Education. 10th ed., New Jersey: Pearson.

Blythe, J. (2013). Consumer behavior. Thousand Oaks, CA: Sage Publications.

Boeing upgrades aircraft forecast. (2018). TR Weekly. Available at: https://tinyurl.com/y9fonf8d [Accessed 1 Oct. 2018].

Byrne, B. M., Shavelson, R. J. and Muthén, B. (1989). Testing for the equivalence of factor covariance and mean structures: The issue of partial measurement invariance.

Psychological Bulletin, 105(3), pp. 456-466. Available at: doi: 10.1037//0033-2909.105.3.456

Byun, H., Lee, B. and Rye, J. (2014). A comparative study on evaluating the service quality attributes based on Kano Model: A case of low-cost carrier and full-service carrier. SHS Web of Conferences, 12. Available at: doi: $0.1051 /$ shsconf $/ 20141201017$ 
Centre for Aviation. (2018). Thailand low-cost airlines: Rapid growth as fleet triples in 5 years. Available at: https://tinyurl.com/y7b76dda [Accessed 1 Oct. 2018].

Chang, H. H., and Chen, W. W. (2008). The impact of online store environment cues on purchase intention, trust, and perceived risk as a mediator. Online Information Review, 32(6), pp. 818-841. Available at: doi: $10.1108 / 14684520810923953$

Chau, P. Y. K. (1997). Reexamining a model for evaluating information center success using a structural equation modeling approach. Decision Sciences, 28(2), pp. 309 - 334. Available at: doi: 10.1111/j.1540-5915. 1997.tb01313.x

Charoensuthipan, P. (2018, August 27). Korea visa-free arrivals still in effect. Bangkok Post. Available at: https:/ / tinyurl.com/ycng7zo7 [Accessed 1 Oct. 2018].

Chaudury, A. and Holbrook, M. B. (2001). The chain of effects from brand trust and brand affect to brand performance: The role of brand loyalty. Journal of Marketing, 65(2), pp. 81-93. Available at: doi: 10.1509/jmkg.65.2.81.18255

Chen, Y-S. and Chang, C-H. (2013). Towards green trust: The influences of green perceived quality, green perceived risk, and green satisfaction. Management Decision, 51(1), pp. 63-82. Available at: doi: $10.1108 / 00251741311291319$

Cho, M., Bonn, M. A. and Kang, S. (2014). Wine attributes, perceived risk and online wine repurchase intention: The cross-level interaction effects of website quality. International Journal of Hospitality Management, 43(0), pp. 108120. Available at: doi: 10.1016/j.ijhm.2014.09.002

Chou, C-C., Liu, L-J., Huang, S-F., Yih, J-M. and Han, T-C. (2011). An evaluation of airline service quality using the fuzzy weighted SERVQUAL method. Applied Soft Computing, 11(2), pp. 2117 - 2128. Available at: doi: 10.1016/j.asoc.2010.07.010

Cox, D. F. (1967). Introduction. In: D.F. Cox, ed., Risk taking and information handling in consumer behaviour (p.15). Boston, MA: Harvard University Press.

Curry, N. and Gao, Y. (2012). Low-cost airlines-A new customer relationship? An analysis of service quality, service satisfaction, and customer loyalty in a low-cost setting. Services Marketing Quarterly, 33(2), pp. 104 - 118. Available at: doi: 10.1080/15332969.2012.662457

de Villiers, R. (2015). Customer brand enmeshment: Typography and complexity modeling of customer brand engagement and brand loyalty enactments. Journal of Business Research, 68(9), pp. 1953 - 1963. Available at: doi: 10.1016/j.jbusres.2015.01.005

DuPont, G. (2015). Southeast Asia aviation: What you need to know. New Airport Insider. Available at: https:/ / tinyurl.com/19dw6vf [Accessed 1 Oct. 2018].

DuPont, G. (2017). Thailand Aviation: What Happened to It? New Airport Insider. Available at: https:/ / tinyurl.com/y8pa8d65 [Accessed 1 Oct. 2018].

Ehbara, R. A. and Shukor, S. A. (2016). Impact of service quality factors on customer trust in Libyan airline industry. International Journal of Academic Research in Business and Social Sciences, 6(5), pp. 350-363. Available at: doi: $10.6007 /$ ijarbss/v6-i5/2153

Fornell, C. and Larcker, D. F. (1981). Evaluating structural equation models with unobservable variables and measurement error. Journal of Marketing Research, 18(1), pp. 39-50. Available at: doi: https:// doi.org/10.2307/3151312

Frost, J. (2017). How to interpret R-squared in regression analysis. Available at: https://tinyurl.com/ydygpckw

Gefen, D. (2002). Customer Loyalty in E-Commerce. Journal of the Association for Information Systems, 3(1), pp. 27 - 51. Available at: https:/ / tinyurl.com/y7rbjvcx [Accessed 1 Oct. 2018].

Ghotbabadi, A. R., Feiz, S. and Baharun, R. (2016). The relationship of customer perceived risk and customer satisfaction. Mediterranean Journal of Social Sciences, 7(1), pp. 161- 173. Available at: doi: 10.5901/mjss. 2016.v7n1s1p161

Gilbert, D. and Wong, R. K. C. (2003). Passenger expectations and airline services: A Hong Kong-based study. Tourism Management, 24(5), pp. 519-532. Available at:

doi: 10.1016/s0261-5177(03)00002-5

Goldenberg, B. J. (2015). The definitive guide to social CRM: Maximizing customer relationships with social media to gain market insights, customers, and profits. Upper Saddle River, New Jersey: Paul Boger.

Grant, L. (2017). Qantas 2017 investor day. Available at: https://tinyurl.com/yd39xbym [Accessed 3 Oct. 2018].

Gregg, D. G. and Walczak, S. (2010). The relationship between website quality, trust and price premiums at online auctions. Electronic Commerce Research, 10(1), pp. 1-25.

Available at: doi: 10.1007/s10660-010-9044-2

Hair, J. F., Hult, G. T. M., Ringle, C. and Sarstedt, M. (2016). A primer on partial least squares structural equation modelling (PLS-SEM). Thousand Oaks, CA: Sage. 
Haryono, S., Suharyono, Fauzi, A. D. H. and Suyadi, I. (2015). The effects of service quality on customer satisfaction, customer delight, trust, repurchase intention, and word of mouth. European Journal of Business and Management, 7(12), pp. 36 - 48. Available at: http:/ / tinyurl.com/hgpqhw2 [Accessed 1 Oct. 2018].

Heracleous, L. and Wirtz, J. (2010). The Globe: Singapore Airlines' balancing act. Harvard Business Review, July-August. Available at: http:/ / tinyurl.com/zd9esrq [Accessed 1 Oct. 2018].

Hogan, J. (2017). Tough times set to continue in aviation industry. Arabian Business Info. Available at: https:/ / tinyurl.com/ycmghwqe [Accessed 1 Oct. 2018].

Hooper, D., Coughlan, J. and Mullen, M. (2008). Structural equation modelling: Guidelines for determining model fit. Electronic Journal of Business Research

Methods, 6(1), pp. 53-60. Available at: http:/ / tinyurl.com/zyd6od2 [Accessed 1 Oct. 2018].

Hu, L. T. and Bentler, P. M. (1999). Cutoff criteria for fit indexes in covariance structure analysis: Conventional criteria versus new alternatives. Structural Equation Modeling, 6(1), pp. 1 - 55. Available at: doi: 10.1080/10705519909540118

Hussain, R., Nasser, A. A. and Hussain, Y. K. (2015). Service quality and customer satisfaction of a UAE-based airline: An empirical investigation. Journal of Air Transport Management, 42, pp. 167 - 175. Available at: doi: 10.1016/j.jairtraman.2014.10.001

Hutchins, D. (1985). Achieve Total Quality. UK: Fitzwilliam Publishing.

IATA. (2017). 2017 marked by strong passenger demand, record load factor. International Air Transport Association. Available at: https: / / tinyurl.com/y9kwlhgo [Accessed 1 Oct. 2018].

Jacoby, J. and Kaplan, L. (1972). The components of perceived risk. Advances in Consumer Research, 3, pp. $382-383$. Available at: https:// tinyurl.com/y9r48lu8 [Accessed 1 Oct. 2018].

Jöreskog, K. G., Olsson, U. H. and Fan, Y. W. (2016). Multivariate analysis with LISREL. Berlin, Germany.

Järveläinen, J. (2007). Online purchase intentions: An empirical testing of a multiple- theory model. Journal of Organizational Computing and Electronic Commerce, 17(1), pp. 53 - 74. Available at: http://tinyurl.com/zgdwsaz [Accessed 1 Oct. 2018].

JD Power. (2018). North America airline satisfaction study. Available at: https://tinyurl.com/y8hvax63 [Accessed 1 Oct. 2018].

Johnson, M. S., Sivadas, E. and Garbarino, E. (2008). Customer satisfaction, perceived risk and affective commitment: an investigation of directions of influence. Journal of Services Marketing, 22(5), pp. 353-362. Available at: doi: 10.1108/08876040810889120

Juran, J. M. and Gryna, F. M. (1998). Juran's quality control handbook. New York, NY: McGraw Hill.

Kim, Y. K. and Lee, H. R. (2011). Customer satisfaction using low-cost carriers. Tourism Management, $32(2)$, pp. 235 243. Available at: doi: $10.1016 /$ j.tourman.2009.12.008

Kline, R. B. (2011). Principles and practice of structural equation modeling. 3rd ed. New York, NY: The Guilford Press.

Kositchotethana, B. (2017). Budget carriers' passenger traffic continues to soar. Bangkok Post. Available at: http:/ / tinyurl.com/len4qpe [Accessed 1 Oct. 2018].

Kotler, P. and Armstrong, G. (2002). Marketing: An introduction. Englewood Cliffs, NJ: Prentice-Hall.

Krämer, A., Tachilzik, T. and Bongaerts, R. (2017). Technology and disruption: How the new customer relationship influence the corporate strategy. In: A. Khare, B. Stewart, and R. Schatz. Eds., Phantom Ex Machina, Springer, pp. 53-70.

Available at: doi: 10.1007/978-3-319-44468-0_4

Krejcie, R. V. and Morgan, D. W. (1970). Determining sample size for research activities. Educational and Psychological Measurement, 30(3), pp. 607 - 610. Available at: doi: 10.1177/001316447003000308

Kulpa, J. (2017). Why is customer relationship management so important? Forbes. Available at: https:/ / tinyurl.com/y8wyl97t [Accessed 1 Oct. 2018].

Kumudha, A. and Bhunia, A. (2016). Customer relationship management and marketing practices in airlines industry - An empirical study. International Journal of

Applied Research, 2(11), pp. 39-43. Available at: https:/ / tinyurl.com/yaly2mtm [Accessed 1 Oct. 2018].

Lau, T-C, Kwek, C-L. and Tan, H-P. (2011). Airline e-ticketing service: How e-service quality and customer satisfaction impacted. International Business Management, 5(4), pp. 200 - 208. Available at: doi: 10.3923/ibm.2011.200.208

Lerrthaitrakul, W. and Panjakajornsak, V. (2014). The airline service quality affecting

post purchase behavioral intention: Empirical evidence from the low-cost airline industry. International Journal of Trade, Economics and Finance. 5(2), pp. 155-158.

Available at: doi: 10.7763/ijtef. 2014.v5.360

Levine, D., Berenson, M. and Krehbiel, T. C. (2011). Basic Business Statistics: Concepts and Applications (12 th ed.). New Jersey: Prentice Hall. 
Larentis, F., Antonello, C. S. and Slongo, L. A. (2018). Organizational culture and relationship marketing: an interorganizational perspective. Review of Business Management, 20(1), pp. 37 - 56. Available at: doi: 10.7819 /rbgn. v20i1.3688

Malthouse, E. C., Haenlein, M., Skiera, B., Wege, E. and Zhang, M. (2013). Managing customer relationships in the social media era: Introducing the social CRM House. Journal of Interactive Marketing, 27(4), pp. 270 - 280. Available at: doi: 10.1016/j.intmar.2013.09.008

Marakanon, L. and Panjakajornsak, V. (2017). Perceived quality, perceived risk and customer trust affecting customer loyalty of environmentally friendly electronics products. Kasetsart Journal of Social Sciences, 38(1), pp. 24 - 30. Available at: doi: 10.1016/j.kjss.2016.08.012

Matell, M. S. and Jacoby, J. (1972). Is there an optimal number of alternatives for Likert-scale items? Effects of testing time and scale properties. Journal of Applied Psychology, 56(6), pp. 506-509. Available at: doi: 10.1037/h0033601

Morgan, R. M. and Hunt, S. D. (1994). The commitment-trust theory of relationship marketing. The Journal of Marketing, 58(3), pp. 20-38. Available at: doi: 10.2307/1252308

Munusamy, J., Chelliah, S. and Pandian, S. (2011). Customer satisfaction delivery in airline industry in Malaysia: A case of low-cost carrier. Australian Journal of Basic and Applied Sciences, 5(11), pp. 718-723.

Nyhan, R. C. and Marlowe, H. A. (1997). Development and psychometric properties of the organizational trust inventory. Evaluation Review, 21(5), pp. 614-635. Available at: doi: 10.1177/0193841x9702100505

Olshavsky, R. W. and Kumar, A. (2001). Revealing the actual roles of expectations in consumer satisfaction with experience and credence goods. Journal of Consumer

Satisfaction, Dissatisfaction, and Complaining Behaviour, 13. Available at: http://jcsdcb.com/index.php/JCSDCB/article/view/106 [Accessed 1 Oct. 2018].

Pakdil, F. and Aydin, O. (2007). Expectations and perceptions in airline services: An analysis using weighted SERVQUAL scores. Journal of Air Transport Management, 13(4), pp. 229-237. Available at: doi: 10.1016/j.jairtraman.2007.04.001

Park, J. W., Robertson, R. and Wu, C. L. (2004). The effect of airline service quality on passengers' behavioural intentions: A Korean case study. Journal of Air Transport Management, 10(6), pp. 435-439. Available at: doi: 10.1016/j.jairtraman.2004.06.001

Rasch, G. (1980). Probabilistic models for some intelligence and attainment tests. Chicago, IL: university of Chicago Press.

Reichheld, F. F. and Sasser, W. E. (1990). Zero Defections: Quality Comes to Services. Harvard Business Review, September/October, pp. 105-111.

Ringle, C. M., Sarstedt, M. and Zimmermann, L. (2011), Customer satisfaction with commercial airlines: The role of perceived safety and purpose of travel. Journal of

Marketing Theory and Practice, 19(4), pp. 459 - 472. Available at: doi: 10.2753/mtp1069-6679190407

Roselius, T. (1971). Consumer rankings of risk reduction methods. Journal of Marketing, 35(1), pp. 56-61. Available at: doi: $10.2307 / 1250565$

Saha, G. C. (2009). Service quality, satisfaction, and behavioural intentions: A study of low-cost airline carriers in Thailand. Managing Service Quality: An International Journal, 19(3), pp. 350-372. Available at: doi: 10.1108/09604520910955348

Schiffman, L. G. and Wisenblit, J. L. (2015). Consumer behavior. 11 th ed., New Jersey: Pearson.

Schumacker, R. E. and Lomax, R. G. (2010). A beginner's guide to structural equation modeling. 3rd ed., New York, NY: Routledge.

Srisook, P. and Panjakajornsak, V. (2017). Southeast Asian low-cost carrier airline competitiveness: A solution for economic growth. Business and Economic Horizons, 13(4), pp. 536-555. Available at: doi: 10.15208/beh.2017.37

Tani, M. (2018). Southeast Asia airlines face yet thinner profits in 2018. Nikkei Asia Review. Available at: https:/ / tinyurl.com/yb5wdk2o [Accessed 1 Oct. 2018].

Tavakol, M. and Dennick, R. (2011). Making sense of Cronbach's alpha. International Journal of Medical Education, 2, pp. 53 - 55. Available at: doi: 10.5116/ijme.4dfb.8dfd

Telus International. (2017). Improving customer satisfaction in the airline industry. Available at: https:/ / tinyurl.com/ybu75g24 [Accessed 1 Oct. 2018].

Thai Airways Annual Report. (2017). Annual report 2017 Thai Airways International Public Company Limited. Available at: https:/ / tinyurl.com/y83appu6 [Accessed 1 Oct. 2018].

Thai Airways. (2018, July 18). THAI wins three Skytrax Awards 2018. Available at: https:/ / tinyurl.com/yczgyr9o [Accessed 1 Oct. 2018].

The International Trade Administration. (2018). Thailand - Aviation. U.S. Department of Commerce. Available at: https:/ / tinyurl.com/yb8sylrb [Accessed 1 Oct. 2018].

TIBCO. (2017). Airline customer loyalty and improving your bottom line with data you already have. Available at: https:/ / tinyurl.com/ydz4tmra [Accessed 3 Oct. 2018]. 
UNWTO. (2018). UNWTO tourism highlights 2017 edition. United Nations World

Tourism Organization. Available at: https://tinyurl.com/ybvjmows [Accessed 1 Oct. 2018].

Yang, K-C., Hsieh, T-C., Li, H. and Yang, C. (2012). Assessing how service quality, airline image, and customer value affect the intentions of passengers regarding low-cost carriers. Journal of Air Transport Management, 20, pp. 52-53. Available at: doi: 10.1016/j.jairtraman.2011.12.007

Vuthisopon, S. and Srinuan, C. (2017). Low cost carrier passenger repurchase intention:

A structural equation model analysis. Asia-Pacific Social Science Review, 17(2), pp. 249-266. Available at: https:/ / tinyurl.com/y88zbfey [Accessed 1 Oct. 2018].

Wan, C. (2017). AirAsia: The journey to becoming a digital airline has begun. WIT. Available at: http:/ / tinyurl.com/mph2uzd [Accessed 1 Oct. 2018].

Zeithaml, V. A., Parasuraman, A. and Berry, L. L. (1990). Delivering quality service. Balancing customer perceptions and expectations. New York, NY: The Free Press. 